\title{
RECYCLING OF CORUNDUM PARTICLES - TWO-BODY ABRASIVE WEAR OF POLYMERIC COMPOSITES BASED ON WASTE
}

\author{
Petr Valášsek, Miroslav Müller, Sergej Hloch
}

Original scientific paper

Recycling of all materials should be supported by modern society. Material recycling is one of the most important ways of dealing with waste. One of material recycling possibilities is an inclusion of waste into primary matrices. A suitable ratio and a combination of waste particles influence in a positive way mechanical properties of the material in which they are dispersed and they decrease its price. An example of the mentioned material recycling is a dispersion of corundum waste particles in the polymeric matrix. The combination of these types of matrix and filler gives birth to new polymeric particles composite - creates a qualitatively brand new material. As most important characteristics of the polymeric particle composites, one often lists resistance to abrasive wear, hardness, impact resistance and strength and, last but not least, their cost. This article deals mostly with the two-body abrasive wear resistance and hardness of polymeric particle composites with the waste $\mathrm{Al}_{2} \mathrm{O}_{3}$ as filler and two-component epoxy matrix.

Keywords: corundum; epoxy resin; hardness; porosity; tribology

Recikliranje čestica korunda - abrazivno trošenje između dva tijela od polimernih kompozita na temelju otpada

Izvorni znanstveni članak Moderno bi društvo trebalo podržavati recikliranje svih materijala. Recikliranje materijala jedan je od najvažnijih načina tretiranja otpada. Jedna od mogućnosti recikliranja materijala je uključivanje otpadnih materijala u primarne matrice. Odgovarajući omjer i kombinacija otpadnih čestica na pozitivan način utječu na mehanička svojstva materijala u kojem su raspršene, a smanjuju mu i cijenu. Primjer recikliranja spomenutog materijala je disperzija čestica otpada korunda u polimernoj matrici. Kombinacija takvih vrsta matrica i punila dovodi do novog kompozita polimernih čestica - stvara kvalitativno sasvim novi materijal. Kao najvažnije značajke kompozita od polimernih čestica često se navode otpornost na abrazivno trošenje, tvrdoća, otpornost na udar i čvrstoća, i zadnje, ali ne manje važno, cijena. Rad se uglavnom bavi otpornošću na abrazivno trošenje između dva tijela i tvrdoćom kompozita od polimernih čestica s otpadnim $\mathrm{Al}_{2} \mathrm{O}_{3}$ kao punilom i dvo-komponentnom matricom od epoksidne smole.

Ključne riječi: epoksidna smola; korund; poroznost; tribologija; tvrdoća

\section{Introduction}

Composite materials satisfy with their properties more exacting needs of modern engineering. Composite systems consist of two or more phases with different mechanical, physical and chemical properties, whose mutual interaction then influences the resulting characteristics and behavior. The individual phases influence the resulting characteristics of the material by their own characteristics and by the mutual interaction of the matrix and the filler. The filler can improve the value of mechanical properties like resistance to abrasive wear, hardness, impact resistance and can reduce the cost. To describe a polymeric particle composite as a material system it is necessary to specify, apart from the specifications of material components and their characteristics, the geometry of the supports in relation to the system. This geometry can be described by its shape, size and distribution of parts $[1 \div 3]$.

All parameters influencing the characteristics of composite materials are related either to their structure, or to the relations between phases. Mutual coherence of the system is important - cohesion, an interaction in the interface of particles and the matrix and last but not least adhesion of the system to a basis (as far as it is required).

By adding the corundum particles to the epoxy, we can influence a number of resulting characteristics. Satapathy et al. [4] found out in their experiments that for epoxy with primary corundum filler with particle size of $40 \div 100 \mu \mathrm{m}$, the inclusion of corundum increased resistance to abrasive wear. Similar results were achieved by Basavarajappa et al. [5], who describe a significant positive influence of $\mathrm{SiC}$ micro-particles on the resultant three-body abrasive wear resistance of the polymeric matrices. Mohan et al. [6] used in their experiment also Si particles, they describe the improvement of tribologic properties of the polymeric composites filled with the particle size of the $20 \div 25 \mu \mathrm{m}$. Valášek [7] uses in his experiments iron metal chips from processes of milling and machining for increasing an abrasive wear resistance of reactoplastics.

Epoxy resin as the matrix is brittle and prone to the initiation of cracks. The interface of microparticles and an epoxy resin can increase a proneness of the system to initiation of cracks which shows itself with decreasing values of strength characteristics and impact strength. $\mathrm{Ku}$ et al. [8] optimized the tensile and bending strength of epoxy and phenolic resins by adding microparticles of smaller sizes. Also Satapathy et al. [4] reached similar results with corundum particles at the tensile strength of epoxy resins.

Increasing other mechanical properties than the wear resistance of the material is described by Cerbu and Curtu [9], who mention using the recycled rubber together with the glass fibres at the epoxy resins - the presence of recycled rubber particles led to the increasing of the impact strength.

Particles composites distinguished for increased abrasive wear resistance are applied in the area of industry and agriculture at renovation of machine parts and in the area of connecting materials $[10 \div 12]$.

During the process of the matrix hardening sedimentation occurs at particle composite systems. A control of particles distribution can be carried out by means of a reduction coefficient with using X-ray 
radiation. For interpretation of results GD degree of grey and the Eq. (1) can be used:

$$
\frac{G D L}{G D O}=\mathrm{e}^{-\mu x}
$$

where:

GDL - level of grey in place of ray going through testing specimen,

GDO - level of grey for ray which did not go through testing specimen [13].

Shots of the grey value (level) give information about the material and the reduction coefficient of X-rays in each point on the shot. Nowadays there exists an effort to correct other effects which would enable to convert the level of grey to values which are directly proportional to e.g. local density of the material [14].

The article deals with a polymeric particle composite based on abrasive waste in interaction with twocomponent epoxy resin. The abrasive waste is represented by abrasive corundum grain $\left(\mathrm{Al}_{2} \mathrm{O}_{3}\right)$ with different grain sizes. This waste category belongs to the class 120117 in the Czech waste catalogue. This group is not put in the attachment No. 5 of the Statute book 185/2001 about waste, therefore it is not a case of groups of dangerous waste and their handling is in the Czech Republic (as in the European Union) in no way limited by legislation. This manner of recycling is tolerant to the environment, creates new material and presupposes lower costs of the composite system. The production of this type of waste is not negligible in the Czech Republic nor in the EU countries (see Fig. 1). Almost $40 \%$ of the total amount of this waste was tipped - without possibility to use in the year 2011 [15]. The tipping is not in accordance with the EU priorities, that is why the material using this type of waste is still topical. The idea to use waste particles from blasting in the form of the epoxy resins fillers is protected in the Czech Republic by the utility pattern 22122 (Polymeric particle composite on the basis of waste, authors Müller and Valášek).

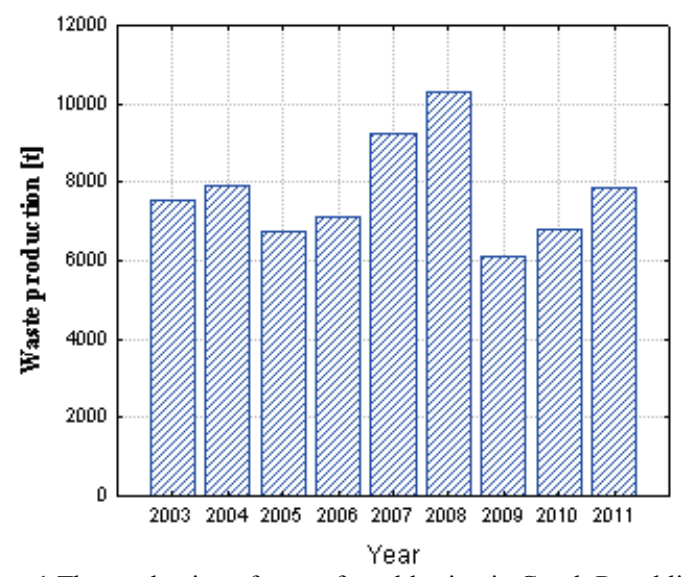

Figure 1 The production of waste from blasting in Czech Republic [15]

The aim of this experiment is to describe the behaviour of the polymeric composite on the basis of waste corundum micro particles of various sizes depending on their changing ration and to compare chosen properties with industrially used polymeric materials (PA 6, Material S, Epros In). The experiment is based on a hypothesis coming from above mentioned references that microparticles will lead to a vehement increase of the abrasive wear resistance. The paper focuses namely on the two-body abrasion and the hardness.

\section{Methodology}

For carried out experiments the two-component epoxy resin ECO-EPOXY 1200/324 with the curing agent P11 (based on bisphenol A) was chosen. The curing time of this resin is 24 hours at $23{ }^{\circ} \mathrm{C}$. The total curing occurs after 7 days. The filler was represented by the waste which did not show dangerous properties. As filler, the waste from mechanical surface preparations was used: waste abrasive particles from blasting - synthetic corundum of fractions F60 $(284 \pm 68 \mu \mathrm{m})$, F80 $(153 \pm$ $36 \mu \mathrm{m}), \mathrm{F} 240(47 \pm 9 \mu \mathrm{m}), \mathrm{F} 400(15 \pm 6 \mu \mathrm{m})$, and F800 $(5,7 \pm 1,1) \mu \mathrm{m}$. The synthetic corundum was taken from a sand blaster where common carbon steel sheets were blasted (grit blasted area corresponded to $820 \mathrm{~cm}^{2}$ ). The microparticles size after the blasting process was measured on the stereoscopic microscope. Composite systems were prepared with filler volume percentage of 5 , $10,15,20,25$ and $30 \%$. The formulation of the filler part by volume eliminates the influence of the different density between the matrix $\left(1,15 \mathrm{~g} / \mathrm{cm}^{3}\right)$ and the filler (we worked with complete surface wettability of the grains with density of the corundum at $4,0 \mathrm{~g} / \mathrm{cm}^{3}$ ). The mixture of epoxy resin and microparticles was mixed mechanically in an ultrasound basin to prevent the emergence of air bubbles and to guarantee the mixture homogeneity. On purpose, other ways (e.g. vacuum) were not used for the testing samples preparation and this was owing to the linking up with the practice where the need to minimize costs for the preparation and application of these systems is assumed.

The two body abrasion was tested on a rotating cylindrical drum device with the abrasive cloth of the grain size $\mathrm{P} 220\left(\mathrm{Al}_{2} \mathrm{O}_{3}\right.$ grains $)$ according to the standard CSN 62 1466. The testing machine with the abrasive cloth consists of the rotating drum on which the abrasive cloth is affixed by means of a bilateral adhesive tape. The testing specimen is secured in the pulling head and during the test it is shifted by means of a moving screw along the abrasive cloth from the left edge of the drum to the right one, (see Fig. 2). The testing specimen is in the contact with the abrasive cloth and it covers the distance of $60 \mathrm{~m}$. During one drum turn of $360^{\circ}$ it is provoked the testing specimen left above the abrasive cloth surface. Consequent impact of the testing specimen simulates the concussion. The pressure force is $10 \mathrm{~N}$. The mean of the testing specimens was $15,5 \pm 0,1 \mathrm{~mm}$ and their height was $20,0 \pm 0,1 \mathrm{~mm}$. The mass decreases were measured on analytic scales weighing on $0,1 \mathrm{mg}$. The volume decreases were calculated on the basis of the found out volume and the density of the composite systems. The highest temperature value observed in the interface of the testing sample and the abrasive cloth was recorded by a contactless thermometer Testo 845 .

As guide for the hardness determination of the composite systems the standard CSN EN ISO 20391 was used. The testing specimens dimensions were 
of $35 \times 25 \times 9 \mathrm{~mm}$. The hardness was measured in the bottom, respectively in a settled part of the specimen and it was because of the fact that also the abrasive wear was found out in this part of the specimens. The distribution of the filler in the matrix caused by the gravitation force depends on its concentration, particles shape, form etc. and it shows itself on the hardness values. [7] Because of the size of the filler, a ball of hard metal with the diameter $D$ $=10 \mathrm{~mm}$ was used (see Fig. 3). The testing specimens $\left(35 \times 25 \times 9 \mathrm{~mm}-\right.$ see Fig. 4 , where $F_{g}$ stands for the sense of the gravitation force affecting the sample) were loaded using the force of $2,452 \mathrm{kN}$ for the duration of $30 \mathrm{~s}$. Average values stated in this paper do not contain extremes which would be set aside from the statistical data sets on the basis of normal distribution (one statistical data set consists of 15 measurements).

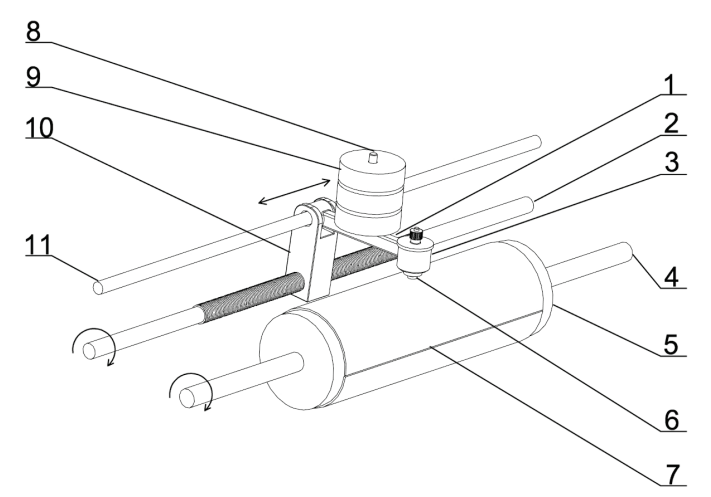

Figure 2 Schema of equipment for two-body abrasive wear testing

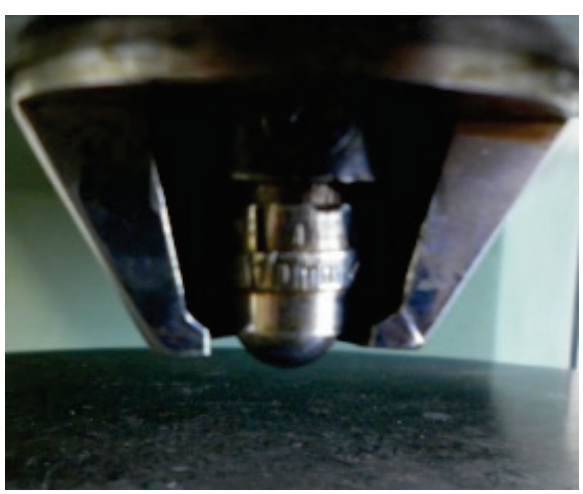

Figure 3 Hardness tester

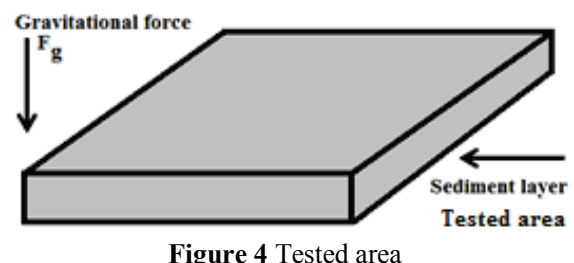

The porosity was set on the basis of the theoretical and real density difference which characterizes the quality of composite systems. When calculating the porosity, the theoretical density respectively, the matrix density $1,15 \mathrm{~g} / \mathrm{cm}^{3}$ and the corundum density $4,0 \mathrm{~g} / \mathrm{cm}^{3}$ where reasoned. The composite theoretical density ranges from $1,29 \mathrm{~g} / \mathrm{cm}^{3}$ to $2,01 \mathrm{~g} / \mathrm{cm}^{3}$. The real density was calculated on the basis of exact sizes and weight of testing specimens $(35 \times 25 \times 9 \mathrm{~mm})$.

A statistical evaluation of results was carried out by means of the program Statistica - ANOVA, reliability level $\alpha=0,05$.

Results of the experiment were compared with commercially used polymeric materials:

- PA 6 - wear resistant polymeric material, density $0,93 \mathrm{~g} / \mathrm{cm}^{3}$.

- Material S - wear resistant polymer, density $1,16 \mathrm{~g} / \mathrm{cm}^{3}$.

Epros In - two-component putty used for renovation of machine parts surfaces, density $1,7 \mathrm{~g} / \mathrm{cm}^{3}$.

\section{Results}

The porosity values are graphically expressed by means of Fig. 5, a statistical evaluation of graphical presentation is visible in Tab. 1.

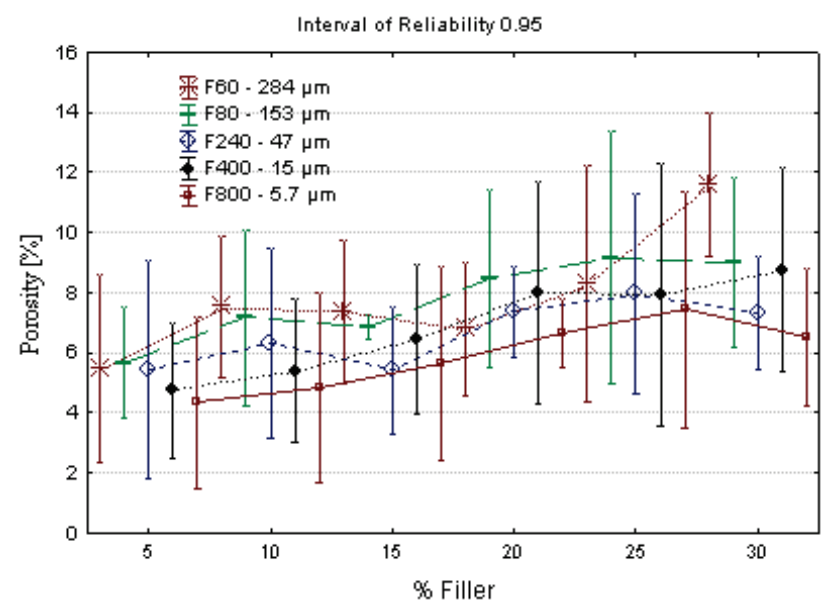

Figure 5 Porosity of composite systems

Air pores have already been found out by the optical analysis by the stereoscopic microscope in the unfilled resin whose real density corresponds to the density stated by the producer. The pores quantification would be difficult so that is why porosity of the unfilled resin was not presented in the graph.

Table 1 Statistical evaluation - ANOVA

\begin{tabular}{|c|c|c|}
\hline Material & $F(5 ; 12)$ & $p$ \\
\hline $\mathrm{F} 60-284 \mu \mathrm{m}$ & 10,1281 & 0,00 \\
\hline $\mathrm{F} 80-153 \mu \mathrm{m}$ & 4,5835 & 0,01 \\
\hline $\mathrm{F} 240-47 \mu \mathrm{m}$ & 2,8634 & 0,06 \\
\hline $\mathrm{F} 400-15 \mu \mathrm{m}$ & 4,6268 & 0,01 \\
\hline $\mathrm{F} 800-5,7 \mu \mathrm{m}$ & 2,9633 & 0,05 \\
\hline
\end{tabular}

The hardness (HBW) of composite systems can be found in Fig. 6, representing the changes in hardness in individual percent concentrations of filler in the matrix ( 5 $\div 30 \%$ ) in dependence on the used fraction. The fraction is represented in the graph by average particle sizes. The results are graphically compared with PA 6, Material S and Epros In.

It is apparent from the graph that hardness decreases in correlation to the decreasing particle size. At the same time, hardness increases in correlation with the relative 
amount of filler in the matrix. The statistical evaluation arising from the graph is stated in Tab. 2 .

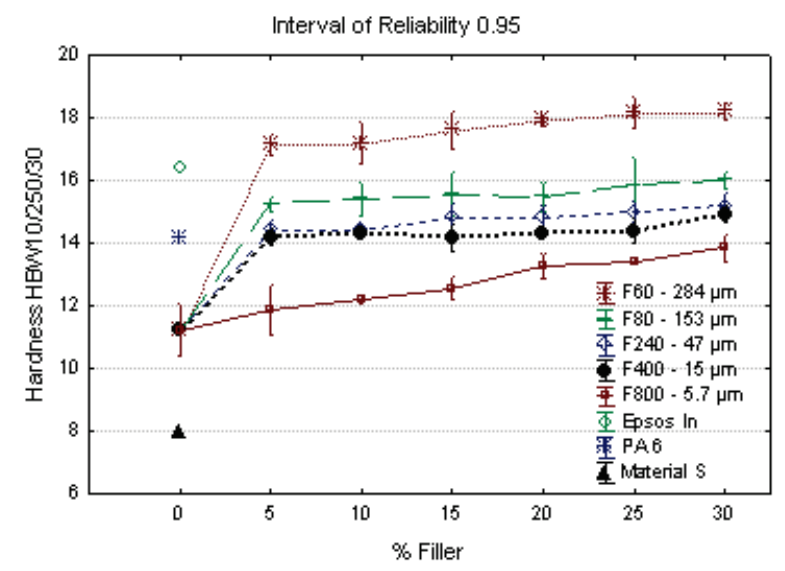

Figure 6 Hardness of composite systems

Table 2 Statistical evaluation - ANOVA

\begin{tabular}{|c|c|c|}
\hline Material & $F(6 ; 14)$ & $p$ \\
\hline F60 - 284 $\mu \mathrm{m}$ & 412,8952 & 0,00 \\
\hline F80 - $153 \mu \mathrm{m}$ & 141,9302 & 0,00 \\
\hline F240 - 47 $\mathrm{m}$ & 172,8596 & 0,00 \\
\hline F400 - 15 $\mu \mathrm{m}$ & 151,8804 & 0,00 \\
\hline $\mathrm{F} 800-5,7 \mu \mathrm{m}$ & 62,0955 & 0,00 \\
\hline
\end{tabular}

The highest values were recorded at $30 \%$ filler in the matrix with the F60 fraction (HBW 10/250/30 18.21). The variability of hardness, in the graph, can be explained by the unequal distribution of the filler in the matrix, caused for example by sedimentation or the potential contamination of the filler (resulting from the secondary nature of the raw material). The lowest value of hardness, (HBW 10/250/30 11.85) was recorded for the F800 fraction with $5 \%$ filler in the matrix. The hardness of resin without any filler was HBW 10/250/30 11.22.

Resistance to abrasive wear is apparent in the following Fig. 7. With the decreasing average particle size, the composite systems' resistance to abrasive wear also decreases.

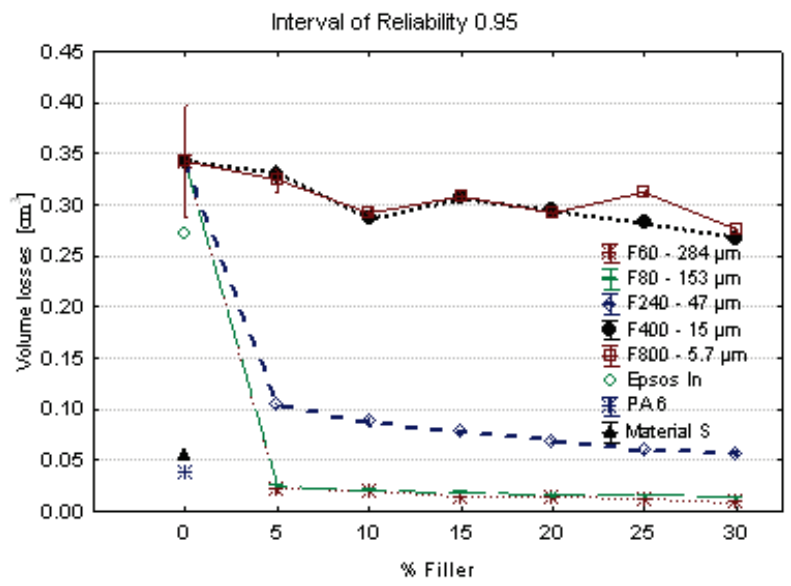

Figure 7 Volume loss of composite systems

The sample least susceptible to abrasive wear was the F60 fraction with $30 \%$ filler in the matrix, with the volume loss of only $0,009 \mathrm{~cm}^{3}$. This volume loss is about $97 \%$ lower than the epoxy volume loss. The highest volume loss was recorded for the F800 fraction. The statistical evaluation following graph is stated in Tab. 3 .

Table 3 Statistical evaluation - ANOVA

\begin{tabular}{|c|c|c|}
\hline Material & $F(6 ; 14)$ & $p$ \\
\hline F60 - 284 $\mu \mathrm{m}$ & 666,1652 & 0,00 \\
\hline F80 - 153 $\mathrm{m}$ & 655,3247 & 0,00 \\
\hline F240 - 47 $\mathrm{m}$ & 449,7013 & 0,00 \\
\hline F400 - 15 $\mathrm{m}$ & 30,5858 & 0,00 \\
\hline F800 - 5,7 $\mathrm{m}$ & 20,8826 & 0,00 \\
\hline
\end{tabular}

The composite system cut and subsequent shot from the optical analysis of the phases of the composite worn area is presented in Fig. 8. This optical analysis could be carried out on used type of the stereoscopic microscope only till the used fraction size F240 that is why it is not presented more complex.

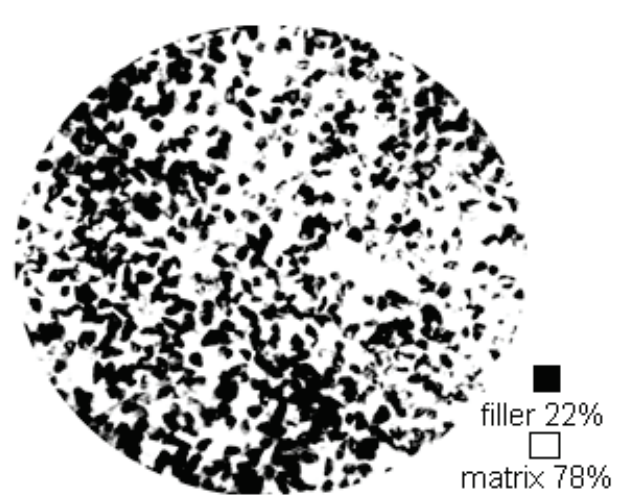

Figure 8 Optical analysis of phases of $5 \%$ filler concentration (F60)

\section{Discussion}

The conducted experiments confirmed the presumption based on the works of authors $[1,4,6,11$, 12] who claimed that the inclusion of filler in the matrix of epoxy resin increases hardness and resistance to abrasive wear. The composite porosity was confirmed, the occurrence of air pores influences the mechanical properties of the composite in the negative way. The filler sedimentation at lower concentrations at large middle sizes of particles was evident which confirms the conclusions of the authors $[7,13]$. In accordance with the experiment results this fact leads to the conclusion that saturated systems are suitable from the wear resistance point of view - they excel in high wear resistance and they are not prone to the sedimentation (in the case of the experiment - concentrations $25 \%, 30 \%$ ).

The resulting figures of hardness and resistance to abrasive wear depend upon the size of the filler particles. Based on the results of the experiment, it is safe to conclude that the ideal size of the filler particles most positively influencing the monitored characteristics of the systems at used abrasive cloth P220 would be the one found in the F60 and F80 fractions (average particle size $284 \div 153 \mu \mathrm{m})$. Smaller particle sizes than these, the ones in F240, F400 and F800 fractions $(47 \div 5,7 \mu \mathrm{m})$, have a positive impact on both their hardness and resistance to abrasive wear, but their values are in lower order digits than those of the larger particles. The particle composites ability to resist to the abrasion at the abrasive cloth with bonded abrasive depends on the size of used abrasive 
particles both at the composite systems and the abrasive cloth. This fact has to be considered at planning possible application areas for these composite systems.

Nowadays, on the basis of carried out experiments the implementation of these composite materials based on the waste corundum into the practice is taking place, and this is done in cooperation with the Czech agricultural companies. One of possible application areas is the renovation of parts of machines processing the soil (see Fig. 9). Following up the experiment prototypes of ploughing blades, land side and exchangeable parts of a mouldboard were developed. Their functional steel surface was adjusted by these composite systems and nowadays practical tests are taking place (Fig. 10).

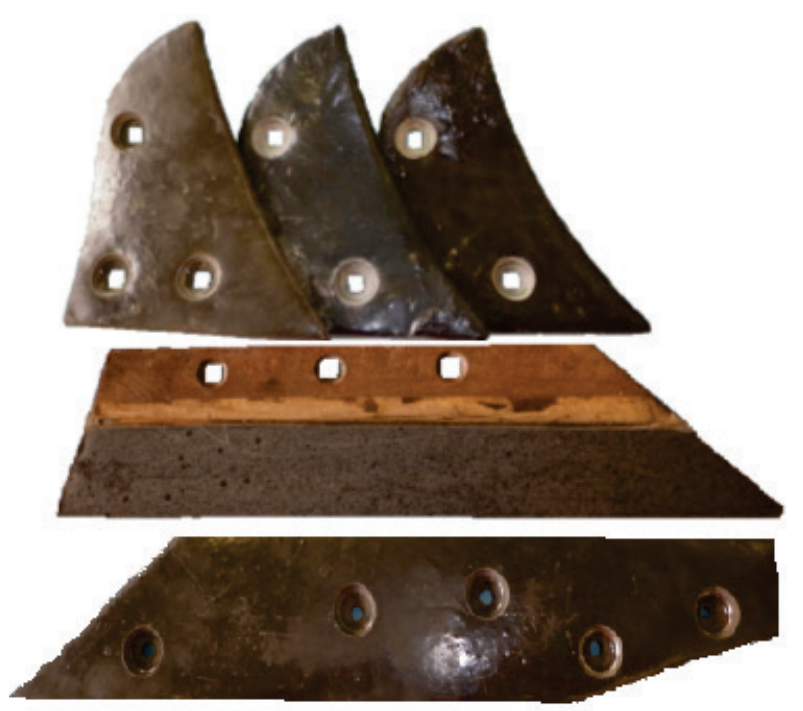

Figure 9 Prototypes of exchangeable parts of mouldboard and land side with composite layer (F60, F80 a F240)

An advantage of filled polymeric materials based on the filler in the form of waste is their decreased adhesion when processing damp soil and connected arising friction influencing the consumption of fuels.

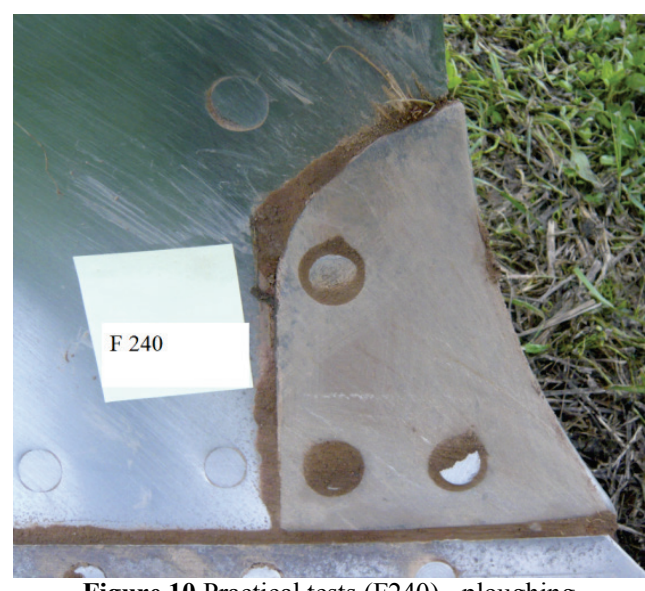

Figure 10 Practical tests (F240) - ploughing

From the experiment results it is visible that in the area of polymeric particle composites it is possible to replace the primary raw material (filler) by a secondary one. This possibility of recycling of synthetic corundum is very considerate to the environment and also saves costs necessary for the creation of a particle composite system.
The successful experiments confirmed the presupposition necessary for the application of polymeric particle composites with waste-based filler in industry and agriculture. Their high resistance to abrasive wear, increased hardness, low density and available costs predestine these systems for applications used for puttying, the renovation of mechanical parts and functional areas. What is not to be overlooked is also that with choosing the correct area of application, also different characteristics than hardness and resistance to abrasive wear are important, such as tensile strength and impact strength.

\section{Conclusion}

The hypothesis about considerable increase of the wear resistance and the hardness by the inclusion of hard inorganic particles based on the waste - corundum was confirmed:

- The composite with middle grain size $284 \mu \mathrm{m}$ showed $16 \%$ higher hardness and $97 \%$ lower volume losses than the unfilled system.

- From the abrasive wear point of view the sufficient strength in the interface of the epoxy matrix and the waste filler was proved which did not lead to a delamination of particles during the experiment.

- This fact predetermines the polymeric matrix as a bearer of the material recycling of particles waste.

\section{Acknowledgement} TF.

This paper has been done when solving the grant IGA

\section{References}

[1] Kim, B. Ch.; Park, S. W.; Lee, D. G. Fracture toughness of the nano-particle reinforced epoxy composite. // Composite Structures. 86(2008), pp. 69-77.

[2] Gay, D; Suong, W. H.; Stephen, W.T. Composite Materials - design and application, CRC Press LLC, 531 p., 2003.

[3] Vojtech, D. Materials and their marginal status, VŠCHT, Prague, 2010.

[4] Satapathy, B. K.; Bijwe, J. Analysis of simultaneous influence of operating variables on abrasive wear of phenolic composites. // Wear. 253(2002), pp. 787-794.

[5] Basavarajappa, S.; Joshi, A. G.; Arun, K.; Kumar, A. P.; Kumar, M. P. Three-Body Abrasive Wear Behaviour of Polymer Matrix Composites Filled with SiC Particles. // Polymer-Plastics Technology and Engineering. 14(2010), pp. 8-12.

[6] Mohan, N.; Natarajan, S.; Kumaresh Babu, S. P. The role of synthetic and natural fillers on three-body abrasive wear behaviour of glass fabric-epoxy hybrid composites. // Journal of Applied Polymer Science. 124(2012), pp. 484494.

[7] Valasek, P.; Muller, M.; Proshlyakov, A. Effect of sedimentation on the final hardness of polymeric particle composites. // Research of Agriculture Engineering, 58(2012), pp. 92-98.

[8] Ku, H.; Trada, M. et al. Tensile Tests of Phenol Formaldehyde Glass-Powder Reinforced composites: Pilot Study. // Journal of Applied Polymer Science. 116(2010), pp. 10-17. 
[9] Cerbu, C.; Curtu, I. Mechanical characterization of the glass fibres/rubber/resin composite material. // Materiale Plastice. 48, 1(2011), pp. 93-97.

[10] Valasek, P.; Muller, M. Composite based on hard-cast irons utilized on functional parts of tools in agrocomplex. // Scientia Agriculturae Bohemica. 3(2013), pp. 172-177.

[11] Valasek, P.; Muller, M. Polymeric particle composites with filler saturated matrix. // Manufacturing Technology, 12, 13(2013), pp. 55-59.

[12] Muller, M.; Valasek, P.; Novák, P. et al. Aplikace návarů a kompozitů $\mathrm{v}$ oblasti technologie pěstování a sklizně cukrové řepy (Welding and composites applications in the field of technology growing and harvesting sugar beets). // Listy cukrovarnické a řepařské (Sugar and sugar beet journal), 9(2011), pp. 304-307.

[13] Valasek, P.; Proshlyakov, A.; Müller, M. Využití RTG záření $\mathrm{k}$ určení vnitřní struktury technických materiálů polymerních částicových kompozitů (Using X-ray to defining inner structure of technical materials - polymeric particle composites). // Strojírenská technologie. 17, 4(2012), pp.266-270.

[14] Phillip, D. H.; Lannutti, J. J. Measuring physical density with X-ray computed tomography. // NDT \& EInt. 30(1997), pp. 339-350.

[15] Waste evidence (Online). Available: http://isoh.cenia.cz/ groupisoh/fin.php. (Accessed 20-Jul-2013).

\section{Authors' addresses}

Petr Valášek, Ing, Ph.D.

Department of Material Science and Manufacturing Technology, Faculty of Engineering, Czech University of Life Science, Kamýcká 129, 165 21, Prague, Czech Republic,

E-mail: valasekp@tf.czu.cz

Miroslav Müller, Assoc. prof., Ing, Ph.D.

Department of Material Science and Manufacturing Technology, Faculty of Engineering, Czech University of Life Science,

Kamýcká 129, 165 21, Prague, Czech Republic,

E-mail: muller@tf.czu.cz

Sergej Hloch, Assoc. prof., Ing, Ph.D.

Faculty of Manufacturing Technologies of Technical University of Košice with a seat in Prešov,

Bayerova 1, 08001 Prešov, Slovak Republic

Institute of Geonics of the CAS, v. v. i.

Studentska 1768, 70800 Ostrava-Poruba, Czech Republic

E-mail: hloch.sergej@gmail.com 